\title{
THE EFFECTS OF VIBROACOUSTICALLY INDUCED MICROVIBRATIONS ON ARTERIAL BLOOD PRESSURE AND OXIDATIVE STRESS IN RATS
}

Dusko Kornjaca' ${ }^{1}$, Vladimir Zivkovic ${ }^{2}$, Nevena Barudzic², Vladimir Jakovljevic ${ }^{2}$, Dragan Djuric ${ }^{3}$ ${ }^{1}$ Independant Medical Practice, Novi Sad

${ }^{2}$ Department of Physiology, Faculty of Medical Sciences, University of Kragujevac ${ }^{3}$ Institute of Medical Physiology “Richard Burian", Faculty of Medicine, University of Belgrade, Serbia

\author{
EFEKTI VIBROAKUSTIČKI IZAZVANIH MIKROVIBRACIJA NA \\ ARTERIJSKI KRVNI PRITISAK I OKSIDACIONI STRES KOD PACOVA

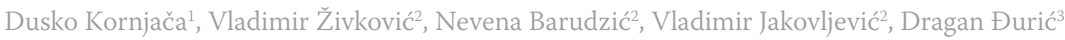 \\ ${ }^{1}$ Nezavisna medicinska praksa, Novi Sad \\ ${ }^{2}$ Katedra za fiziologiju, Fakultet medicinskih nauka, Univerzitet u Kragujevcu \\ ${ }^{3}$ Institut medicinske fiziologije "Ričard Burian”, Medicinski fakultet, Univerzitet u Beogradu, Srbija
}

\section{ABSTRACT}

Vibroacoustics, a scientific field that has been intensively studied for the last thirty years, uses the properties of sound waves (infrasound, ultrasound, noise and music) to induce vibrations that, like a sound wave, may have both useful and harmful effects. The aim of this study was to examine the effects of vibroacoustically induced microvibrations on arterial blood pressure and markers of oxidative stress in the blood. The experiments were performed on Wistar male rats that had a 180-200 g body mass and were divided into control and experimental groups (6 rats in each). In the experimental group, microvibrations were induced using the Vitafon vibroacoustic apparatus (Vitafon, St. Petersburg, Russian Federation), which delivers sound waves of varying frequencies by a process called "phoning." Up to 60 minutes of phoning time was delivered to the kidney and liver using 4 different regimens that included a 5-minute stabilisation time; up to four 10-minute phoning regimens, with 5-minute breaks between each single regimen, at a $30 \mathrm{~Hz}-18000 \mathrm{kHz}$ frequency range; and $2.8 \mu \mathrm{m}-12.3 \mu \mathrm{m}$ microwave amplitudes. After the completion of a phoning regimen, animals were sacrificed and the oxidative stress markers were measured in blood samples $\left(\mathrm{O}_{2}^{-}, \mathrm{H}_{2} \mathrm{O}_{2}\right.$, nitrites, lipid peroxidation index, superoxide dismutase, catalase, and glutathione) and compared with the values of markers in the control group. Systolic arterial pressure was analysed after the acute application of up to four different regimens of vibroacoustic microvibrations. Systolic arterial pressure decreased significantly during the administration of the second regimen in comparison to the control group. Systolic arterial pressure returned, almost completely, to the initial value after the administration of the third and fourth regimens. There was no significant change in diastolic arterial pressure after the acute administration of up to four different regimens, although the pressure decreased slightly after the first and second regimens and returned to the initial value during the administration of the third and fourth regimens. Analysis of oxidative stress markers showed a statistically significant change in the catalase level. No statistically significant differences were found in the other oxidative stress
\end{abstract}

\section{SAŽETAK}

Vibroakustika je naučna oblast koja se intezivno razvija u poslednjih trideset godina, koristi mogućnost zvuka (infrazvuk, ultrazvul, buka i muzika), izaziva vibracije koje kao i zvuk može imati korisne ili štetne posledice. Cilj ovog rada je bio da se ispita uticaj vibroakustično indukovanih mikrovibracija na arterijski krvni pritisak $i$ markere oksidacionog stresa u krvi pacova. Eksperimenti su izvedeni na pacovima Vistar soja, telesne težine 180-200 g, podeljenih u kontrolnu i eksperimentalnu grupu od po 6 životinja. U eksperimentalnoj grupi, mikrovibracije su indukovane pomoću vibroakustičnog aparata (Vitafon, Sankt Peterburg, Rusija) sa ukupno 60 minuta u četiri različita aplikaciona režima (5-minuta-stabilizacija, 10minuta "foniranje" režim i na svakih 5-minuta pauza između signalnih režima, opseg frekvencija $30 \mathrm{~Hz}-18000$ kHz, amplituda mikrotalasa 2,8 $\mu m-12,3 \mu m$, foniranje na jetru $i$ bubreg). Nakon završetka eksperimentalnog protokola, životinje su žrtvovane $i$ markeri oksidacionog stresa su analizirani u uzorcima $\left(\mathrm{O}_{2}, \mathrm{H}_{2} \mathrm{O}_{2}\right.$, nitriti, indeks lipidne peroksidacije, superoksid dismutaza, katalaza, glutation) i poredeni sa vrednostima kontrolne grupe. Analizom vrednosti sistolnog arterijskog pritiska posle akutne primene vibroakustičkih mikrovibracija različitog režima delovanja zabeležen je statistički značajan pad sistolnog arterijskog pritiska prilikom primene drugog režima u odnosu na kontrolu. Uočava se da se sistolni arterijski pritisak posle primene vibroakustičkih mikrovibracija u trećem $i$ četvrtom režimu vratio na gotovo početnu vrednost. Analizom vrednosti dijastolnog arterijskog pritiska posle akutne primene vibroakustičkih mikrovibracija različitog režima delovanja nije zabeležen statistički značajan pad dijastolnog arterijskog pritiska niti u jednom režimu delovanja. Prilikom primene režima tri $i$ četiri vrednosti dijastolnog arterijskog pritisaka su se vratile gotovo na početnu vrednost. Dobijeni rezultati su pokazali statistički značajnu razliku u vrednostima katalaze, dok nije bilo promene u vrednostimaostalih analiziranih parametara. 
markers analyzeanalysed. Further research is needed to clarify the physiological effects of low compared to high frequencies of vibroacoustically induced microvibrations and their possible therapeutic significance.

Key words: vibroacoustics, arterial blood pressure, oxidative stress, microvibrations
Dalje istraživanje je neophodno kako bi se definisali efekti niskih naspram efekata visokih apliciranih frekvencija, odnosno mogući terapijski značaj registrovanih efekata.

Ključne reči: vibroakustika, arterijski krvni pritisak, oksidacioni stres, mikrovibracije

\section{ABBREVIATIONS}

CAT - catalase

GSH - reduced glutathione MAP - mean arterial pressure RBCs - red blood cells

SEM - standard error mean
SD - standard deviation

SOD - superoxide dismutase

TBA - thiobarbituric acid

TBARs - index of lipid peroxidation

TCA - trichloroacetic acid

\section{INTRODUCTION}

Rohracher found that the body surface of humans, or more generally homeotherms, produced constant vibrations, which he named microvibrations (1). The most significant observation of his intensive work is that the sources of these microvibrations are the heart rate and vascular and muscle activities, which produce microvibrations in the infrasound and sound range, respectively. Rohracher further showed that maintenance of microvibrations in an organism demands considerable muscle engagement, or energy consumption and that the amplitude of microvibrations is a sensitive psychophysical measure of muscle tension and total body activity. For example, in a healthy human (or other homeothermic animal), the amplitude of these microvibrations is 1-5 international units at rest, with a frequency range of 6-12 Hz/sec (vibrations per second). Rohracher demonstrated that it is possible to detect microvibrations that, originating in the striated muscle system, over the whole body; contractions of striated muscles have a manifold magnification of the amplitude of microvibrations but do not affect their frequency; and microvibrations are constant during the registration of frequency.

Although Rohracher examined two variables, amplitude and frequency, his discoveries on frequency were of vital importance for his conclusions. The fact that muscles produce movements of various amplitudes had been known, but the finding that they show constant periodic movements with a constant frequency had significant and far-reaching implications. Based on Rohracher's studies, three important facts of microvibration frequency have been defined:

1. It is always within a range of 6-12 cycles per second

2. It is constant with any measurement

3. It varies between measurements that are taken on different occasions in the same subjectand is and is random and not correlated with other variables, as observed by that were Rohracher.
Several studies have been done performed that support Rohracher's conclusions $(2,3,4,5,6,7)$. Based on these studies, the aim of this paper was to examine the acute effects of vibroacoustic microvibrations on arterial blood pressure and markers of oxidative stress in blood.

\section{MATERIAL AND METHODS}

\section{Experimental protocol}

The experiments were performed on Wistar albino rats, aged 8 weeks, with a body weight of 230-250 g. The rats were placed in experimental and control groups, with and $n=6$ in each group, and. Experiments were carried out on each animal individually. All research procedures were carried out in accordance with the Declaration of Helsinki (last updated in 2005) and principles of Good Laboratory Practice (GLP) and were approved by the Ethical Committee for the Welfare of Experimental Animals, Faculty of Medical Sciences, University of Kragujevac. Baseline measurements were obtained for all of the parameters tested in rats without prior exposure to vibroacoustically induced microvibrations, which were used as controls. Rats were exposed to acute vibroacoustically induced microvibrations of defined amplitude and frequency using two vibroacoustic device emitters applied to the skin in the topographical area of the liver and kidney. The following settings on the vibroacoustic device (Vitafon, St. Petersburg, Russian Federation) were used: regimen 1 , lower frequency of the $1^{\text {st }}$ subrange within the limits $30-60 \mathrm{~Hz}$; regimen 2 , upper frequency of the 1st subrange within the limits $1-3 \mathrm{kHz}$; regimen 3 , lower frequency of the $2^{\text {nd }}$ subrange within the limits $0.3-0.8 \mathrm{kHz}$; regimen 4 , upper frequency of the 2 nd subrange within the limits 9-18 kHz; number of microvibration frequency subranges, 2 ; length of a single cycle of microvibration frequency change, $80-160 \mathrm{sec}$; amplitude of microvibra- 
tion at the lowest frequency for settings 1 and of 3, 2.8$5.4 \mu \mathrm{m}$ and for settings 2 and 4, 6-12.3 $\mu \mathrm{m}$; and period of impulse modulation, $0.5-1.2 \mathrm{sec}$. The duration of vibroacoustically induced microvibration stimulation was $60 \mathrm{~min}$. divided into individual $10 \mathrm{~min}$. regimens, with 5 min. breaks between each.

\section{Haemodynamic measurements}

All animals were anaesthetised $(35 \mathrm{mg} / \mathrm{kg}$ sodium pentobarbital; i.p.). The mean arterial pressure (MAP) was determined directly through the femoral artery catheter (PE-50, Clay-Adams, Parsippany, NY, USA) using a low-volume displacement transducer (P23 Db, Statham, Oxnard, CA, USA) and was recorded on a direct writing recorder.

\section{Measurement of oxidative stress parameters in rat blood}

Rats were anesthetizised with ether and sacrificed using cervical dislocation. For both control and experimental groups, $\mathrm{n}_{1 / 2}=12$. Blood was collected in tubes (12x100), with 50 I.J. heparin $/ \mathrm{ml}$ of blood, and kept frozen at $-20^{\circ} \mathrm{C}$ until used for biochemical measurements. The following parameters of redox status were determined spectrophotometrically from the blood samples: index of lipid peroxidation (measured as TBARS ), SOD, CAT and GSH. The presence of thiobarbituric acid reactive substances (TBARs) was used to estimate the degree of lipid peroxidation in plasma by adding $1 \%$ thiobarbituric acid (TBA) in $0.05 \mathrm{M} \mathrm{NaOH}$ to an aliquot of plasma followed by a $15 \mathrm{~min}$. incubation at $100^{\circ} \mathrm{C}$ and reading at $530 \mathrm{~nm}$. Distilled water was used as a blank probe. A TBA extract was obtained by combining $0.8 \mathrm{~mL}$ of plasma and $0.4 \mathrm{~mL}$ of trichloroacetic acid (TCA), incubating the sample on ice for 10 minutes and centrifuging the sample for $15 \mathrm{~min}$. at $6000 \mathrm{rpm}$, as described previously (8). To calculate the activity of endogenous antioxidants, hhaemoglobin was measured according to the Drabkin method (9). Isolated red blood cells (RBCs) were washed three times with 3 volumes of ice-cold $0.9 \mathrm{mmol} / \mathrm{L} \mathrm{NaCl}$ and hemolysate containing approximately $50 \mathrm{~g} \mathrm{Hb} / \mathrm{L}$ prepared. Superoxide dismutase (SOD) activity was determined by the epinephrine method. A $100 \mu \mathrm{L}$ sample of lysate was mixed with $1 \mathrm{~mL}$ of carbonate buffer followed by addition of $100 \mu \mathrm{L}$ of epinephrine. Detection of SOD was performed at $470 \mathrm{~nm}$. (10). Catalase (CAT) activity was determined according to Beutler (11). Lysates were diluted with distilled water $(1: 7 \mathrm{v} / \mathrm{v})$ and treated with chloroform-ethanol $(0.6: 1 \mathrm{v} / \mathrm{v})$ to remove haemoglobin. The sample $(100 \mu \mathrm{L})$ was mixed with $50 \mu \mathrm{L}$ of catalase buffer and $1 \mathrm{~mL}$ of $10 \mathrm{mM} \mathrm{H} 2 \mathrm{O} 2$. Detection of CAT was performed at $360 \mathrm{~nm}$. Distilled water was used as a blank probe. The level of reduced glutathione (GSH) was determined by the oxidation of GSH with 5 , 5-dithiobis- 6 , 2-nitrobenzoic acid using the Beutler method (12). The concentration of oxidative stress parameters is expressed as nanomoles per millilitre of red blood cells (RBCs).

\section{Statistical analysis}

Statistical analysis of experimental data included the following basic descriptive statistics: the mean value $(\mathrm{X})$, standard deviation (SD) and standard error mean (SEM). For testing the normality of distribution parameters, the Kolmogorov-Smirnov test was used. To test the statistical significance of the results and to confirm the hypothesis, the following statistical tests were used: Student's t-test (parametric test), for dependent and independent variables and the Mann Whitney $U$ test, for differences between the parameters. A database analysis of the results was performed using software package SPSS 10th 0 (SPSS Inc., Chicago, IL, USA). Ap $<0.05$ was considered statistically significant.

\section{RESULTS}

\section{Acute effects of vibroacoustic microvibrations of a specified amplitude and frequency on the arterial blood pressure of rats in vivo}

Acute effects of vibroacoustic microvibrations of a specified amplitude and frequency on the arterial blood pressure of rats in vivo

An analysis of systolic arterial pressure after the acute application of vibroacoustic microvibrations using different regimens over the rat's body (5-minute single phoning time, with 5-minute breaks between single regimens) showed a statistically significant decrease of systolic arterial pressure during the administration of the second regimen compared to control ( $\mathrm{p}<0.05)$. A visible decrease in pressure was noted during the administration of the first regimen, but this was not statistically significant. Systolic arterial pressure returned to a nearly baseline level after the administration of the third and fourth regimens of vibroacoustic microvibration (Figure 1).

Diastolic arterial pressure did not decrease significantly after the acute administration of vibroacoustic microvibra-

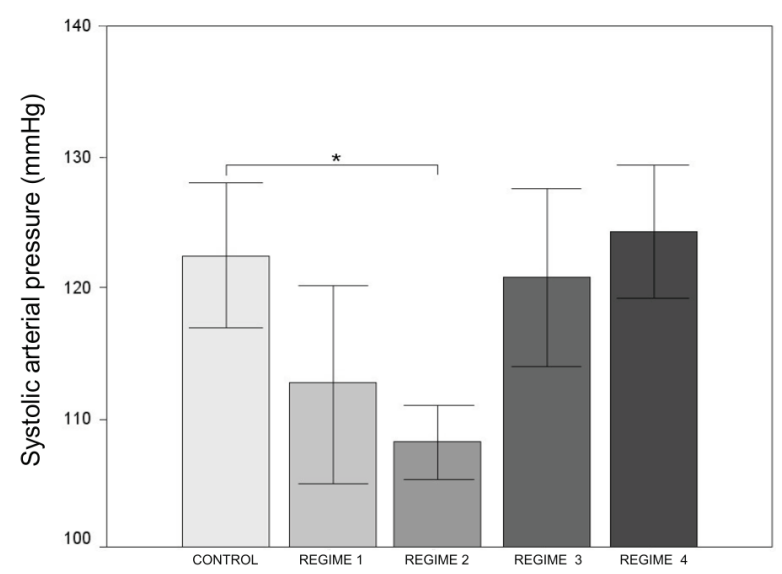

Figure 1. Systolic arterial pressure in rats after acute applications of vibroacoustic microvibrations using 4 various regimens $\left({ }^{*} \mathrm{p}<0.05\right)$ 


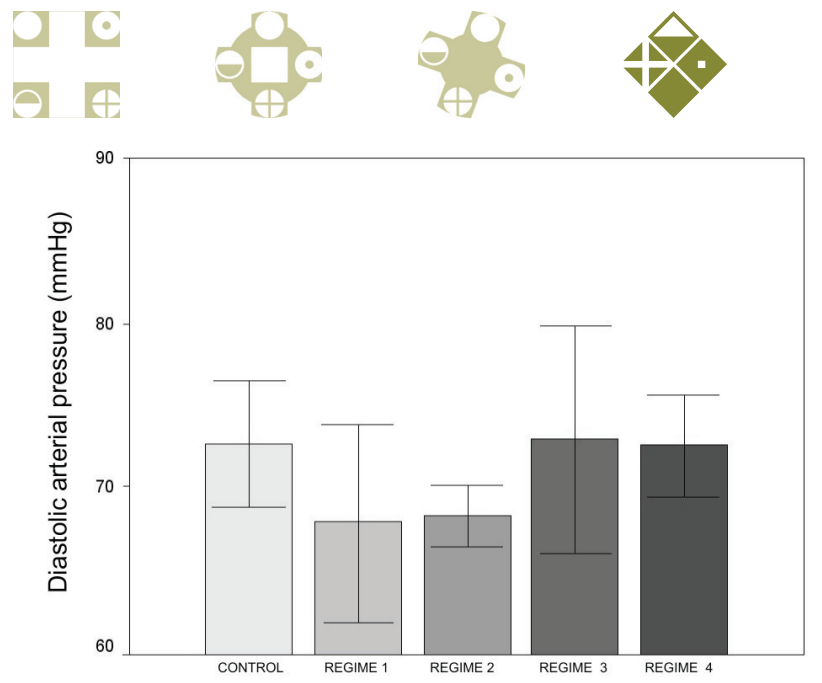

Figure 2. Diastolic arterial pressure in rats after the application of vibroacoustic microvibrations using 4 different regimens

tions using different regimens over the rat's body (5-minute single phoning time, with 5 -minute breaks between single regimens). There was a trend, however, towards decreased diastolic arterial pressure during the first and second regimens, which returned to nearly baseline levels during the administration of the third and fourth regimens (Figure 2).

\section{Acute effects of vibroacoustic microvibrations o a specified amplitude and frequency on oxidative stress parameters in the rat blood}

Analysis of oxidative stress parameters after the acute application of vibroacoustic microvibrations using 4 different regimens (5-minute single phoning time, with 5 -minute breaks, total phoning time 60 minutes) showed a statistically significant increase in the levels of the antioxidative enzyme catalase (CAT). In contrast, TBARs, SOD and GSH levels decreased slightly however this was not statistically significant (Table 1).

\section{DISCUSSION}

Research into the effects of vibrations and sound on human physiology has been the focus of vibroacoustic science for several years because of its significance in the environment (i.e. i.e., the ecology of labour) and in medicine. This research is especially important given the knowledge of the potentially harmful effects of high intensity vibrations on both labourers who work with vibrating machines and devices and the cardiovascular and nervous systems , as well as the harmful effects of high intensity sound on the environment. On the other hand, there are many beneficial effects of vibrations and/or low frequency sound waves, as has been shown recently, with important research being done conducted to study the vibratory sensitivity of people and potential applications of infrasound, ultrasound, noise and music.

Based on his research, Olav Skille (13) pointed to three universal effects of sound and/or music induced vibrations on humans: a. low frequency vibrations can have a relaxing effect, while high frequencies can increase tension; b. "rhythmic" music can excite while non-rhythmic music can have a sedating effect; and c. loud music can lead to aggression, and quiet music can act to sedate.

Vibroacoustic devices, which produce sound-induced vibrations and stimulate humans, were developed withover the last 30 years. Vibroacoustic therapy can be used in clinical settings. For example, music that causes sedation and/or pulse sinusoidal waves with low frequencies (between $20 \mathrm{~Hz}$ and $70 \mathrm{~Hz}$ ) can be applied through a bed or armchair. Vibroacoustic therapy is currently used in the treatment of decubiti, to decrease arterial blood pressure, to reduce the heart rate, to improve circulation in post-operative treatment, and for stress-induced diseases. Reports on the improvement of circulatory beds in lower limbs and positive change of skin colour in patients treated with vibroacoustic therapy are anecdotal evidence of the benefits of this therapy (14). A hydrodynamic pump has been shown by Russian authors, to cause muscle fibres to tremble with sound oscillations, i.e., "a muscle sings at sound frequencies". According to this concept, microvibrations are a physical agent that helps organisms by reducing peripheral resistance in capillary networks and increasing venous blood flow. It has been shown that the role of microvibrations in the pump-like functioning of vascular vessels of the venous and lymphatic systems leads to the unidirectional flow of both blood and lymph. The frequency of smooth muscle trembling in the vascular walls improves the efficiency of venous and lymphatic pumping as well as the amplitude of movement, i.e., oscillations of muscle tissue appears to align with the diameter of the lumen in venous and lymphatic vessels. By applying different regimens of a vibroacoustic stimulator, vibroacoustic waves of various shapes, frequencies, amplitudes and time length can be used to synchronise their energetic stimulation on vessels that can have many different diameters. Each blood or lymphatic vessel will have its own optimum frequency and characteristic energy wave based on its unique diameter. Another important characteristic is a reduction of resistance due to blood circulation. It is assumed that at certain frequencies, vibroacoustic microvibrations decrease the friction between blood layers, thus reducing viscosity and vascular resistance, leading to an increase of "shear stress", which is the main physiological stimulus for the production of nitric oxide (no).

As discussed, there are certain effects of low frequency sound applications on the human cardiovascular system. In a study performed on an Apollo mission, astronauts using infrasound treatment found no electrocardiographic disturbances when 21 male subjects aged 21 and 23 were stimulated by sounds ranging betweenfrom $2 \mathrm{~Hz}-12 \mathrm{~Hz}$, with an intensity of 119-144 decibels, in thea simulation chamber. The heart rate increased in 6 subjects by more than 6 beats per minute during maximum stimulation, but in 5 subjects, the heart rate decreased (15). Respiratory function was evaluated by pneumographic impedance and was normal in all subjects exposed to low frequency stimu- 


\begin{tabular}{|l|l|l|l|}
\hline $\begin{array}{l}\text { Parameter } \\
(\mathbf{X} \pm \mathrm{SE})\end{array}$ & Control & Phoning & $\begin{array}{l}\text { Test and } \\
\text { Significance }\end{array}$ \\
\hline TBARS & $7.28 \pm 1.03$ & $7.25 \pm 0.81$ & $\begin{array}{l}\text { T test } \\
\mathrm{p}=0.984\end{array}$ \\
\hline SOD & $2589.87 \pm 1423.93$ & $2017.36 \pm 1095.60$ & $\begin{array}{l}\text { Mann Whitney } \\
\mathrm{p}=0.937\end{array}$ \\
\hline CAT & $32.04 \pm 4.98$ & $51.29 \pm 1.70$ & $\begin{array}{l}\text { T test } \\
\mathrm{p}=0.010^{* *}\end{array}$ \\
\hline GSH & $68051.66 \pm 3689.26$ & $62066.66 \pm 2824.83$ & $\begin{array}{l}\text { T test } \\
\mathrm{p}=0.227\end{array}$ \\
\hline
\end{tabular}

Table 1. Oxidative stress parameters after the acute application of vibroacoustic microvibrations using 4 different regimens (duration: 60 minutes) (** $\mathrm{p}<0.01)$.

li, while it increased in 6 subjects when a 140 decibel sound was applied. In this study, no discomfort, disorientation, mental confusion, tiredness or decline of mental capacities was found due to the applied vibrations.

In a second study, 40 pilots, divided into three groups, were treated with infrasonic frequencies of $14 \mathrm{~Hz}, 16 \mathrm{~Hz}$ and $50 \mathrm{~Hz}$, respectively; the results showed occasional changes of blood pressure, decreased vigilance and somewhat prolonged reaction time. This study showed that the application of sound in the low infrasound range could impact the working environment and affect efficiency, vigilance and subject behaviour (16). Other studies conducted on healthy people using a frequency of $16 \mathrm{~Hz}$ have not shown significant changes of the heart rate, however, in many cases, the infrasound led to increased diastolic blood pressure and marked reduction of systolic blood pressure (17).

In our study, various regimens of vibroacoustic and acutely induced microvibrations (up to 60 minutes, frequency range $30 \mathrm{~Hz}-18000 \mathrm{~Hz}$, amplitude range $2.3 \mu \mathrm{m}$ $12.3 \mu \mathrm{m})$ were applied to evaluate their effects on arterial blood pressure and oxidative stress parameters in rats.

We measured arterial blood pressure during periods of acute vibroacoustic microvibrations on the body of rats using four different regimens. Systolic arterial pressure, measured after acute application of different regimens of vibroacoustic microvibrations on the body of rats (5-minute phoning per single regime with 5 -minute breaks), decreased significantly during the administration of the second regimen in comparison to the control group. A visible decrease in pressure was noted during the application of the first regimen, but this was not statistically significant. Systolic arterial pressure nearly returned nearly to baseline after the third and fourth regimens of vibroacoustics microvibrations administration.

Diastolic arterial pressure, measured after acute administration of vibroacoustic microvibrations of four different regimens on the body of rats (5-minute phoning per single regime with 5-minute breaks), did not decrease significantly during any regimen, although the pressure tended to decrease during the first and second regimens and returned nearly to baseline after the third and fourth regimens.

Three markers of oxidative stress (TBARS, SOD and GSH), measured after the acute application of four differ- ent regimens of vibroacoustic microvibrations on the body of rats (5-minute phoning per single regime with 5-minute breaks, total phoning time 60 minutes), decreased slightly, but this was not statistically significant. In contrast, the antioxidative enzyme catalase (CAT) increased significantly following the administration of vibroacoustic microvibrations (Table 1).

\section{CONCLUSION}

An acute application of vibroacoustic microvibrations in rats in vivo at low frequencies and amplitudes leads to a significant decrease in systolic arterial pressure (12\%) and a trend towards decreased diastolic arterial pressure.

An acute application of vibroacoustic microvibrations in rats in vivo using 4 different regimens (total time 60 minutes, 5 minutes per single regime with 5 -minute breaks after each) showed a slight decrease in certain markers of oxidative stress; however, this was not statistically significant. In contrast, the there was as statistically significant increase in the catalase (CAT) level.

\section{ACKNOWLEDGEMENTS}

This work is a part of Master of Science's thesis by Dr. Dusan Kornjaca, which was defended at the Faculty of Medical Sciences University of Kragujevac. The authors are especially grateful to the members of the Laboratory for Cardiovascular Research, Institute of Medical Research, University of Belgrade (Dr. Zoran Miloradovic, Dr. Nevena Mihailovic-Stanojevic and Dr. Djurdjica Jovovic) for their expert measurement of arterial blood pressure in rats in vivo.

\section{REFERENCES}

1. Rohracher H. Schwingungen im menchlichen Organismus. Anz. Phil-Hist. Ost Akad. Wiss. 1946; 23.

2. Denier A. The microvibrations of the body as an expression of physiological tone. EEG Clin Neurophysiol. 1957; 9: 362.

3. Heller J. Die Microvibration psychischer Voltage und bei Entspannung. Psychother Med Psychol Z. 1959; 9: 34-38.

4. Luhhan W. Die bei Mikrovibration vorgestellen Bewegungen. Unpublished doctoral dissertation, University of Vienna, 1953 manley RG: Waveform analysis. London: Chapman \& Hall, 1954.

5. Nirrko A. On the intraindividual correspondence between the EEG alpha rhythm and muscle vibration. Report no. 2, University of Helsinki Psychological Institute, 1961.

6. Sugano H. Studies on the microvibrations. Kurume Med J. 1957; 4: 97-113. 
7. Swarofsky H: Die Microvibration bei Affecten und bei Temperaturaenerungen. Unpublishhed doctoral dissertation, University of Vienna, 1958.

8. Ohkawa H, Ohishi N, Yagi K. Assay for lipid peroxides in animal tissues by thiobarbituric acid reaction. Anal Biochem 1979; 95:351-358

9. Drabkin D, Austin H. Spectrophotometric studies II. Preparations from washed blood cells: nitric oxide, hemoglobin and sulfhemoglobin. Journal of Biological Chemistry. 1935; 112: 51-65.

10. Misra HP, Fridovich I. The role of superoxide anion in the autoxidation of epinephrine and a simple assay for superoxide dismutase. Journal of Biological Chemistry. 1972; 10: 3170-3175.

11. Beutler E. Catalase red cell metabolism, a manual of biochemical methods. Grune and Stratton, New York, NY, USA, 1982; 105-106.

12. Beutler E., Reduced glutathione (GSH), in red cell metabolism, a manual of biochemical methods. Grune and Stratton, New York, NY, USA, 1975; 112-114.
13. Skille O. Manual of vibroacoustics. Levanger, Norway: ISVA Publications, 1986.

14. Wigram AL. The effects of vibroacoustic therapy on clinical and non-clinical populations. PhD Thesis, St. Georges Hospital Medical School, London University, 1995.

15. Alford BR, Jerger JF, Coats AC, Bilhingham J, French VCs, McBrayer RO. Human tolerance to low frequency sound. Transactions of the American Academy of Ophthalmology and Otolaryngology 1966; 701: 40-47.

16. Englund K, Hagelthorn G, Hornqvist S, Lidstrom IM, Lindqvist M, L Liszki, Soderberg L. Infraljudets effeckter and människan. In FMV (eds.) Infrasound. A summary of interesting articles. Stockholm: Swedish Defence Materiel Administration, 1978; 22-24.

17. Landstrom U, Danielssen A, Lindmark A, Lindqvist M, Liszki L, Soderberg L. Fysiologiska olchu framkallade under exponering for infraljud. In: FMV (Eds.) Infrasound. A summary of interesting articles. Stockholm: Swedish Defence Materiel Administration. 1981; 44-45 